\title{
Inadequate taxonomy and highly divergent COI haplotypes in laboratory and field populations of earthworms used in ecotoxicology. A case study
}

\author{
Patricks Voua Otomo*, Mark S. Maboeta \& Carlos Bezuidenhout \\ School of Environmental Sciences, North-West University, Private Bag X6001, \\ Potchefstroom, 2520 South Africa \\ Received 23 January 2013. Accepted 27 August 2013
}

\begin{abstract}
DNA barcoding was used to investigate the phylogenetic delimitations of Eisenia sp. populations used in ecotoxicological research in South Africa. A total of three focal groups (used in published works) and two non-focal groups were assessed. These focal groups, including two laboratory cultures and one field population, have been referred to as Eisenia fetida in the literature. A previous molecular study had already helped to establish that one of the two laboratory groups was a population of $E$. fetida's sister species $E$. andrei. In the present contribution, analyses of the COI gene revealed that the taxonomy of the remaining laboratory and field populations had also been incorrectly assigned since all the generated sequences grouped unequivocally with published sequences of $E$. andrei. Very high sequence divergence ( $>25 \%$ K2P) found within $E$. andrei could signal the occurrence of hitherto undescribed cryptic species. These findings are discussed with an emphasis on the possible consequences of using poorly identified earthworms or specimens with high molecular divergence in ecotoxicological bioassays. It is not clear whether unbeknownst to the researchers, the use of cryptic species in bioassays could jeopardise the quality of ecotoxicological investigations. Early evidence suggests that cryptic oligochaete species may respond differently to metal toxicity. The need for comparative ecotoxicological studies between $E$. andrei and $E$. fetida is also evidenced, especially in the light of recent numerous reports of cryptic oligochaete species. Ecotoxicologists are consequently encouraged, whenever possible, to make use of available genomic technologies to screen their laboratory stocks and available field populations for any molecular distinctiveness.
\end{abstract}

Key words: Eisenia fetida, Eisenia andrei, DNA barcoding, oligochaetes, cryptic species.

\section{INTRODUCTION}

The use of DNA barcoding in confirming species identity in the field of ecotoxicology has previously been advocated (Voua Otomo et al. 2009). Eisenia fetida Savigny 1826 and Eisenia andrei Bouché 1972 are especially of interest since both are the recommended earthworm species for the testing of chemicals by the European Organisation of Economic Cooperation and Development (OECD 2004) and the International Standards Organisation (ISO 2005; ISO 2011). The dual recommendation of E. andrei and E. fetida by these organizations was historically based on the fact that these organisms were similar and/or considered to be conspecific.

Previous OECD guidelines (OECD 1984) for instance states that 'Eisenia foetida exists in two races which some taxonomists have separated into

\footnotetext{
*Author for correspondence. E-mail: 23389508@nwu.ac.za /
} o.patricks@yahoo.fr species'. Both E. andrei and E. fetida were, however, described as different species on the basis of their pigmentation (André 1963), although Savigny had originally only identified and described Eisenia foetida in 1826. Bouché (1972) designated them as subspecies, renaming them $E$. foetida foetida (for the current E. fetida) and E. foetida unicolour (for the current $E$. andrei). Despite earlier work by Jaenicke (1982) and Øien \& Stenersen (1984) giving species status to both E. andrei and E. fetida, it is only recently that these species were conclusively proved to be different phylogenetic and biological species (Dominguez et al. 2005; Pérez-Losada et al. 2005).

There is, nonetheless, still a lack of comparative ecotoxicological studies between $E$. andrei and E. fetida to conclude whether they respond differently to environmental pollution since in literature both species are often referred to as E. fetida (Dominguez et al. 2005). Research has revealed 
marked metabolic and reproductive differences between these species (Dominguez et al. 2005; Bundy et al. 2002; Albani et al. 2003). The implications of using inadequate taxonomy in the ecotoxicological context may lead to the erroneous intepretation of results and biased recommendations.

Moreover, numerous reports of cryptic oligochaete species (King et al. 2008; Pérez-Losada et al. 2009; Blakemore et al. 2010; James et al. 2010; Novo et al. 2010) make it a necessity to confirm species identity or authenticate phylogenetic delimitations, especially for those populations and laboratory cultures used for the testing of chemicals under the OECD and ISO frameworks. Cryptic species of the oligochaetes Tubifex tubifex and Lumbricus rubellus have already been shown to differ in terms of their tolerance to metal toxicity (Sturmbauer et al. 1999; Andre et al. 2010).

Apart from their importance as ecotoxicological test species, both E. andrei and E. fetida are also used worldwide in vermicomposting. In many places, vermiculturists have become the main suppliers of live specimens of these worms to research institutes and universities. The necessity of adequate taxonomy may also prove important for commercial earthworm stocks. Beyond the commercial value it may add to vermiculture establishments, correct taxonomic assignments, in this industry, will inevitably have a positive bearing on the reliability of research endeavours in the laboratory.

For reliable identification and genotyping of potential useful specimens of earthworms, DNA barcoding could be the method of choice as it is quick, significantly informative and both its detractors and advocates have agreed on its potential to compliment traditional taxonomy to address identification challenges (Moritz et al. 2004; Hajibabaei et al. 2007; Chang et al. 2009; Rougerie et al. 2009; Chang \& James 2011). Recently, DNA barcoding was used to assess the taxonomic status of several earthworm genera and recommended an extensive revision of the presently accepted earthworm classification (Pérez-Losada et al. 2012).

In the present study, we have undertaken a DNA barcoding investigation of field and laboratory populations of Eisena sp. frequently utilized for ecotoxicological research in South Africa.

\section{MATERIALS \& METHODS}

A total of five Eisenia sp. populations represented by 110 individuals, from North West Province and
Western Cape (South Africa) and Brno (Czech Republic) were included in the present study. Three of these populations have a recorded history in recent ecotoxicological literature (Table 1). The oldest of these is a laboratory stock housed in the Stress Ecology Research Laboratory at the University of Stellenbosch. This laboratory culture was established in the early 1980s with specimens obtained from Braunschweig, Germany. Over the years, this laboratory culture has been enriched genetically through the addition of specimens from local compost heaps. Initially believed to consist of $E$. fetida, it was later found to be $E$. andrei (Voua Otomo et al. 2009). This laboratory stock is included mainly in order to assess the haplotype diversity amongst the different groups. In addition, to the original $16 \mathrm{COI}$ sequences from an earlier study (Voua Otomo et al. 2009), a further 20 sequences from the same stock have been generated in the present study (Table 1). As the oldest population, it is also the one with the most extensive record in the literature (Table 1). A second laboratory culture, housed in the Unit for Environmental Research at North-West University, was started in 2001 with specimens obtained from two local commercial dealers. These commercial earthworm stocks are poorly documented as they were started two to three decades ago with specimens purchased from various sources. This culture has been referred to in the literature as E. fetida. The last population of interest is a field population occasionally sampled from a compost heap at Middelvlei wine farm $\left(33^{\circ} 55^{\prime} 84^{\prime \prime} \mathrm{S}, 49^{\circ} 87^{\prime} 18^{\prime \prime} \mathrm{E}\right.$; Stellenbosch) and has been referred to as E. fetida in the literature (Table 1). Middelvlei wine farm has been in operation since 1819 . We suspect that these earthworms were introduced on the farmland several decades ago through farming practices.

Two non-focal populations (with no record in the ecotoxicological literature) were also included in the present investigation. One is related to the laboratory culture housed at Stellenbosch University; it was started more than two decades ago with specimens from the Braunschweig stock. This population has been used for residential vermicomposting since its establishment. The other non-focal group recently obtained from Brno, Czech Republic, is a laboratory culture believed to be made of $E$. andrei specimens and maintained in the Department of Zoology at North-West University.

Table 1 provides a list of recent publications (last 
Table 1. Origin and literature references of the field population and the laboratory cultures of earthworms included in the present study. The putative name of the species (as reported in the corresponding literature) is provided below the population name. $n /$ ANs indicates the number of specimens used for COI genotyping from the respective populations followed by their respective Genbank accession numbers. $(n)^{*}$ indicates the number of original sequences generated from the culture housed in the Stress Ecology Research Laboratory at Stellenbosch University. All the other sequences were generated in the present study.

\begin{tabular}{|c|c|c|c|c|c|}
\hline $\begin{array}{l}\text { Population } \\
\text { Putative name }\end{array}$ & Type/use & Locality & Code & $\begin{array}{l}n / \\
\text { ANs }\end{array}$ & $\begin{array}{l}\text { Publication record } \\
\text {-selected papers- }\end{array}$ \\
\hline $\begin{array}{l}\text { Stellenbosch } 1 \\
\text { E. fetida }\end{array}$ & Laboratory & $\begin{array}{l}\text { Stress Ecology Research } \\
\text { Laboratory, Stellenbosch } \\
\text { University }\end{array}$ & SUN & $\begin{array}{l}\text { 20/ } \\
\text { JN870005-JN870024 } \\
(16)^{\star} / \\
\text { DQ914618-DQ914633 }\end{array}$ & $\begin{array}{l}\text { Vermeulen et al. 2001; } \\
\text { Reinecke et al. 2001; } \\
\text { Reinecke et al. 2002; } \\
\text { Reinecke \& Reinecke 2003; } \\
\text { Reinecke \& Reinecke 2004; } \\
\text { Maboeta et al. 2004; } \\
\text { Maleri et al. 2007; } \\
\text { Maleri et al. 2008; } \\
\text { Owojori et al. 2009; } \\
\text { Owojori et al. 2010; } \\
\text { Voua Otomo et al. 2009. }\end{array}$ \\
\hline $\begin{array}{l}\text { Stellenbosch } 2 \\
\text { E. fetida }\end{array}$ & Field & $\begin{array}{l}\text { Middelvlei wine farm } \\
\left(33^{\circ} 55^{\prime} 84^{\prime \prime} \mathrm{S}, 18^{\circ} 49^{\prime} 87^{\prime \prime} \mathrm{E}\right)\end{array}$ & MIDD & $\begin{array}{l}\text { 19/ } \\
\text { JN870048-JN870066 }\end{array}$ & $\begin{array}{l}\text { Voua Otomo \& Reinecke } \\
2010 ; \\
\text { Voua Otomo et al. } 2011 .\end{array}$ \\
\hline $\begin{array}{l}\text { Potchefstroom } 1 \\
\text { E. fetida }\end{array}$ & Laboratory & $\begin{array}{l}\text { Unit for Environmental } \\
\text { Sciences Laboratory, } \\
\text { North-West University }\end{array}$ & РОТСН & $\begin{array}{l}\text { 23/ } \\
\text { JN870025-JN870047 }\end{array}$ & $\begin{array}{l}\text { Maboeta \& Van Rensburg } \\
\text { 2003a; } \\
\text { Maboeta \& Van Rensburg } \\
\text { 2003b; } \\
\text { Maboeta et al. } 2008 \text {. }\end{array}$ \\
\hline $\begin{array}{l}\text { Potchefstroom } 2 \\
\text { E. andrei }\end{array}$ & Laboratory & $\begin{array}{l}\text { Department of Zoology, } \\
\text { North-West University }\end{array}$ & $\mathrm{ZOO}$ & $\begin{array}{l}\text { 10/ } \\
\text { JN869995-JN870004 }\end{array}$ & None \\
\hline $\begin{array}{l}\text { Potchefstroom } 3 \\
\text { E. fetida }\end{array}$ & Vermicomposting & $\begin{array}{l}\text { Grimbeek Park, Potchefstroom } \\
\left(26^{\circ} 43^{\prime} 29^{\prime \prime} \mathrm{S}, 27^{\circ} 06^{\prime} 48^{\prime \prime} \mathrm{E}\right)\end{array}$ & VERM & $\begin{array}{l}\text { 22/ } \\
\text { JN870067-JN870088 }\end{array}$ & None \\
\hline
\end{tabular}

decade) utilizing the focal populations discussed as well as the number of specimens per population/laboratory culture included in the present study.

\section{COI genotyping}

Total genomic DNA was extracted using the NucleoSpin ${ }^{\circledR}$ Tissue kit (Macherey-Nagel) from a varying number of earthworms per group (Table 1). We used the universal primers LCO1490 and HCO2198 (Folmer et al. 1994) to amplify $650 \mathrm{bp}$ of the cytochrome oxidase I (COI) gene.

PCR reactions consisted of $0.3 \mu \mathrm{l}( \pm 30 \mathrm{ng}$ ) DNA template, $12.5 \mu$ l PCR Master Mix (Fermentas), $11 \mu \mathrm{l}$ nuclease-free water (Fermentas) and $10 \mathrm{pmol}$ $(\sim 1 \mu l)$ of each of the primers. PCR cycling comprised an initial denaturation step at $94^{\circ} \mathrm{C}$ for $5 \mathrm{~min}$ followed by 35 cycles at $94^{\circ} \mathrm{C}$ for $30 \mathrm{~s}, 50^{\circ} \mathrm{C}$ for $30 \mathrm{~s}$ and $72^{\circ} \mathrm{C}$ for $45 \mathrm{~s}$. A final extension step at $72^{\circ} \mathrm{C}$ for 5 min completed the reactions.
Successful amplification was verified by electrophoretic means using agarose gels $\left(0.75 \mathrm{~g}\right.$ SeaKem ${ }^{\circledR}$ LE Agarose, Lonza- in $50 \mathrm{ml} \mathrm{TAE}$ buffer, $1.5 \% \mathrm{w} / \mathrm{v}$ ) stained with $5 \mu$ l ethidium bromide. Sequencing reactions were performed using the ABIv3.1 BigDye ${ }^{\circledR}$ kit. Purified sequences were run on an ABI 3500XL Genetic analyser.

All the new barcodes generated in the present study were deposited in GenBank (http://www. ncbi.nlm.nih.gov/genbank; ANs: JN869995JN870088). These Eisenia sequences were compared to conclusively identified COI sequences of E. fetida and E. andrei deposited in GenBank and additional sequences (EWSJC613-10 and EWSJC614-10) from the Barcode of Life Data Systems (BOLD, http://www.boldsystems.org). Allolobophoridella eiseni (ANs: AY874492 and AY874487) and Microscolex phosphoreus (AN: AB608785) were used as outgroups.

All the sequences were aligned, edited and 


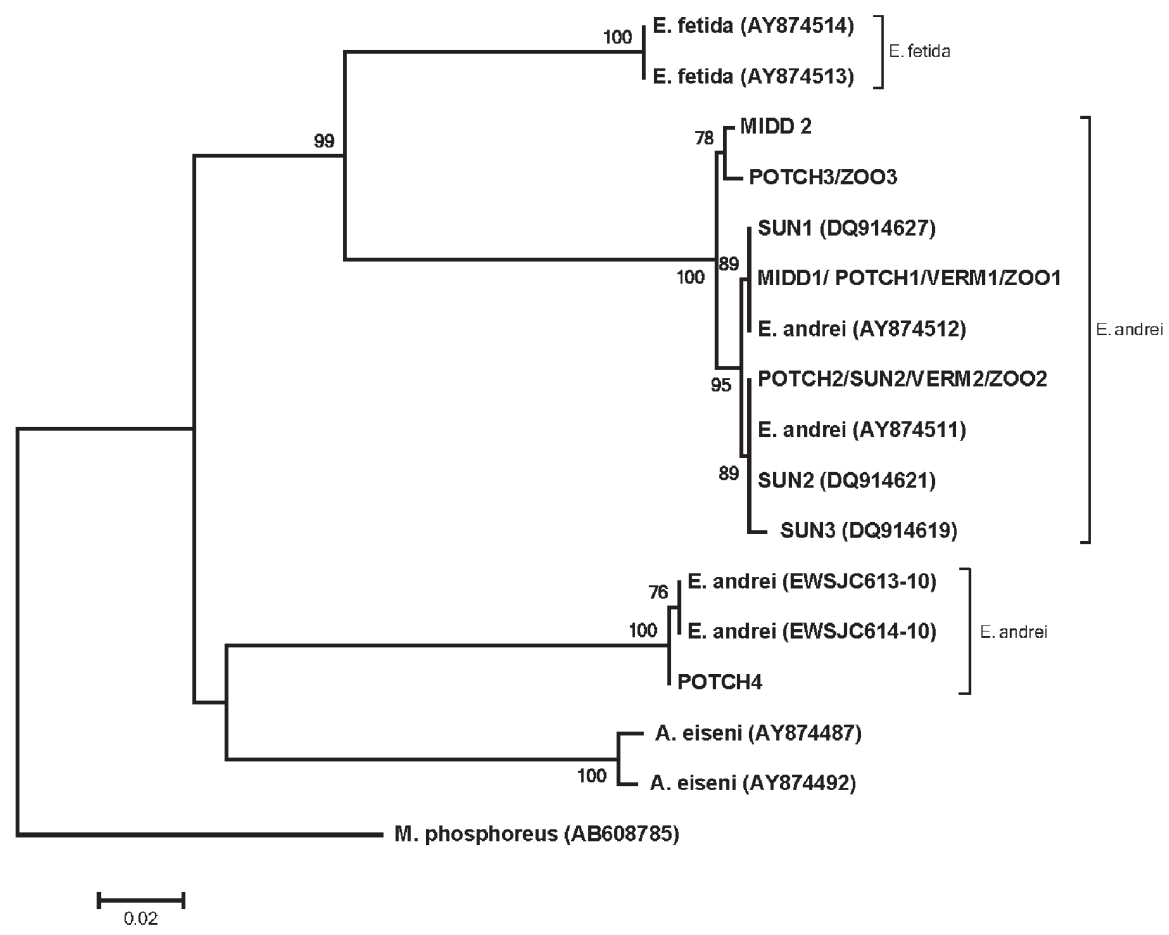

Fig. 1. Phylogenetic tree based on Kimura-2-parameter distances separating all haplotypes identified in the field population and laboratory cultures of Eisenia sp. Bootstrap support obtained for specific nodes are reported. Genbank accession numbers or BOLD process IDs are provided in brackets for the sequences downloaded from either Genbank or BOLD. Allolobophoridella eiseni and Microscolex phosphoreus were included as close and distant relatives to Eisenia sp., respectively. *The grouping of POTCH4 and the BOLD samples from Brazil represents a potential unidentified earthworm species. The ' $E$. andrei' ID is therefore considered dubious.

analysed in MEGA v5 (Tamura et al. 2011). Neighbour-joining $(\mathrm{NJ})$ trees were constructed using the Kimura-2-parameter (K2P) method (Kimura 1980). Bootstrap support was obtained from 1000 iterations.

\section{RESULTS}

Ninety-four new Eisenia sequences were generated in the present study. Of these, $59(62.77 \%)$ were identical to the SUN2 haplotype found in a previous study (Voua Otomo et al. 2009). This shared haplotype was found in all the Eisenia populations/cultures (POTCH2/SUN2/VERM2/ZOO2) except for the field population collected at Middelvlei farm. SUN2 was also the only haplotype found in the 20 additional individuals from the stock culture of the Stress Ecology Research Laboratory at Stellenbosch University. The second most frequent sequence (MIDD1/POTCH1/ VERM1/ZOO1; 31.91\%) was found in all Eisenia populations/cultures except for the SUN laboratory culture [it had however been previously found to occur in that culture - SUN1 haplotype-
Voua Otomo et al. (2009)]. A rare shared haplotype (POTCH3/ZOO3; 3.19\%) was found in both laboratory populations from North-West University and two unique haplotypes (MIDD2 and POTCH4; $1.65 \%$ ) were found in the MIDD field population and the POTCH laboratory population, respectively. The least diverse of all the groups were both the MIDD and the VERM groups with two haplotypes each, while the POTCH culture harbouring four haplotypes was the most diverse.

Phylogenetic analyses showed that all the local Eisenia sequences grouped unequivocally with 100\% bootstrap support, to identified sequences of E. andrei (Fig. 1). The unique haplotype POTCH4 was considerably divergent from the other local sequences (> 23\% K2P). It grouped, nonetheless, with identified BOLD sequences of $E$. andrei. Excluding POTCH4, sequence divergences smaller than $1.75 \%$ and greater than $16.5 \% \mathrm{~K} 2 \mathrm{P}$ separated the new Eisenia sequences with previously identified sequences of E. andrei and E. fetida, respectively. 


\section{DISCUSSION}

None of the populations investigated were found to be E. fetida. This is in contrast to literature evidence from the last decade stating that South African ecotoxicologists have utilized this species. Prior to the widespread use of genomic technologies, a local study compared the growth and reproduction of local earthworms, identified as E. fetida, to E. andrei and E. fetida specimens imported from France (Reinecke \& Viljoen 1991). This was done in an attempt to confirm the identify of the populations occurring in South Africa. Maturation time (development of well-defined clitellia), indicated that these worms 'resembled neither E. fetida nor E. andrei' from France while cumulative cocoon production indicated they 'more closely resembled E. fetida' (Reinecke \& Viljoen 1991). However, with regard to appearance, growth and cocoon hatching success, the local earthworms 'resembled E. andrei more closely'. Consequently, the authors could not conclusively rule on the question and stated that these observations could be either due to the occurrence of mixed local populations or to geographical isolation of these local populations from either of the conspecific populations from France (Reinecke \& Viljoen 1991). There is a strong possibility that these worms may have been E. andrei all along.

Nevertheless, these local populations could have been a mixture of the two species since it is acknowledged that both commonly occur in mixed colonies and that E. andrei could outcompete E. fetida during periods of food abundance (Elvira et al. 1996). E. andrei is believed to be the dominant species in commercial vermiculture establishments (Dominguez et al. 2005) as a consequence of favourable ambient conditions (typified by regular nutrient availability). It is therefore possible that initial mixed populations of E. fetida and E. andrei might have occurred locally (as suggested by Reinecke \& Viljoen 1991) and that over time, E. andrei became the most dominant species. This observation is particularly important for the earthworm laboratory stock housed in the Stress Ecology Research Laboratory at the University of Stellenbosch. This laboratory culture has been enriched with specimens from local sources. This practice could have ultimately resulted in a shift from a predominantly E. fetida culture to the present $E$. andrei stock. Such a practice if not rigorously controlled could, in the long run, jeopardise the integrity of long-term laboratory earthworm cultures.
Accurate taxonomy in the field of ecotoxicology is important since without reliable taxonomy, eco(toxico)logical studies would be irrelevant (Dominguez et al. 2005). The present results would hardly be those of an isolated case study. Ecotoxicological literature reveals that worldwide, countless researchers rely upon informally identified commercial earthworm stocks for laboratory bioassays. In many instances, earthworms are simply collected from the environment and brought to the laboratory prior to ecotoxicological testing. Lowe \& Butt (2007) rightfully argued that the validity of results derived from earthworms of unknown origin must be questioned. Dupont (2009) has acknowledged that 'for the molecular ecologist the problematic taxonomy of earthworms is a critical drawback'.

Our results suggest the occurrence of two distant sequence groups identified as E. andrei: one composed of most of the sequences generated in the present study, the other composed of POTCH4 haplotype and other BOLD sequences. High sequence divergence (as high as $25.24 \% \mathrm{~K} 2 \mathrm{P}$ ) within E. andrei sequences may signal the occurrence of undescribed cryptic species. Such high sequence divergence is beyond the $15 \% \mathrm{~K} 2 \mathrm{P}$ accepted boundary for species separation when using DNA barcodes (Chang \& James 2011). This particular finding adds up to the list of similar abundant reports, in oligochaete species, from the literature (King et al. 2008; Pérez-Losada et al. 2009; Blakemore et al. 2010; James et al. 2010; Novo et al. 2010). It is therefore possible that ecotoxicological testing at the Unit for Environmental Sciences Laboratory at North-West University is being performed on at least two different earthworm species masquerading as E. fetida.

The occurrence of high sequence divergence amongst conspecific earthworms is not surprising considering the fact that these organisms have poor dispersal ability which would make them prone to settle in fragmented populations with little or no gene flow between them (Field et al. 2007; Novo et al. 2009; Mathieu et al. 2010). In the case of the Eisenia sp. the phenomenon could be compounded by the fact that the known habitats of the species (compost heaps, manure-rich soils, etc.) are naturally fragmented. However, it is worthwhile to note that except for the single rare POTCH4 haplotype (found in the Unit for Environmental Sciences Laboratory, North-West University), all the $E$. andrei $\mathrm{COI}$ sequences were in general similar $(<1.8 \% \mathrm{~K} 2 \mathrm{P})$ across populations. 
The origin of the divergent POTCH4 haplotype may not be pinpointed until a more geographically inclusive study is conducted. Local commercial earthworm populations have been poorly documented and often started or were enriched with specimens from several local or international sources. We suspect that the putative E. andrei sequences (of Brazilian origin) retrieved from BOLD and closely related to POTCH4 $(0.19 \%$ K2P) may have been misfiled or simply misidentified. This grouping represents a potentially unidentified earthworm species.

In conclusion, this study highlights a pressing need for reliable traditional and molecular taxonomy in the field of earthworm ecotoxicology. It also uncovers the need for comparative ecotoxicological studies between E. andrei and E. fetida. It is not clear as to how the use of conspecific individuals with increased molecular divergence will impact on the reliability of ecotoxicological testing. Similarly, it is not clear whether unbeknownst to the researchers, the use of cryptic species in bioassays could jeopardise comparative studies using earthworm populations or cultures of diverse origins. Early evidence already suggests that cryptic oligochaete species may respond differently to metal toxicity (Sturmbauer et al.1999; Andre et al. 2010). Consequently, ecotoxicologists are encouraged, whenever possible, to make use of available genomic technologies to screen their laboratory stocks and available field populations for any molecular distinctiveness.

\section{ACKNOWLEDGEMENTS}

The authors wish to acknowledge A.J. and S.A. Reinecke; P. Theron and H. Bouwman for providing some of the materials used in this study. This work was supported by a Post-doctoral fellowship to P. Voua Otomo by North-West University.

\section{REFERENCES}

ALBANI, J.R., DEMUYNCK, S., GRUMIAUX, F. \& LEPRETRE, A. 2003. Fluorescence fingerprints of Eisenia fetida and Eisenia andrei. Photochemistry and Photobiology 78: 599-602.

ANDRÉ, F., 1963. Contribution à l'analyse expérimentale de la reproduction des lombriciens. Bulletin Biologique de la France et de la Belgique 97: 3-101.

ANDRE, J., KING, R.A., STÜRZENBAUM, S.R., KILLE, P., HODSON, M.E. \& MORGAN, A.J. 2010. Molecular genetic differentiation in earthworms inhabiting a heterogeneous $\mathrm{Pb}$-polluted landscape. Environmental Pollution 158: 883-890.

BLAKEMORE, R., KUPRIYANOVA, E. \& GRYGIER, M. 2010. Neotypification of Drawida hattamimizu Hatai, 1930 (Annelida, Oligochaeta, Megadrili,
Moniligastridae) as a model linking mtDNA (COI) sequences to an earthworm type, with a response to the 'Can of Worms' theory of cryptic species. ZooKeys 41: $1-29$.

BOUCHÉ, M.B. 1972. Lombriciens de France. Ecologie et Systématique. Institut National des Recherches Agriculturelles (INRA), (no hors-serie). 72: 1-671.

BUNDY, J.G., SPURGEON, D.J., SVENDSEN, C., HANKARD, P.K., OSBORN, D., LINDON, J.C. \& NICHOLSON, J.K. 2002. Earthworm species of the genus Eisenia can be phenotypically differentiated by metabolic profiling. FEBS letters 521: 115-120.

CHANG, C. \& JAMES, S. 2011. A critique of earthworm molecular phylogenetics. Pedobiologia 54: S3-S9.

CHANG, C., ROUGERIE, R. \& CHEN, J. 2009. Identifying earthworms through DNA barcodes: Pitfalls and promise. Pedobiologia 52: 171-180.

DOMINGUEZ, J., VELANDO, A. \& FERREIRO, A. 2005. Are Eisenia fetida (Savigny, 1826) and Eisenia andrei (Oligochaeta, Lumbricidae) different biological species? Pedobiologia 49: 81-87.

DUPONT, L. 2009. Perspectives on the application of molecular genetics to earthworm ecology. Pedobiologia 52: 191-205.

ELVIRA, C., DOMINGUEZ, J. \& BRIONES, M.J. 1996. Growth and reproduction of Eisenia andrei and E. fetida (Oligochaeta, Lumbricidae) in different organic residues. Pedobiologia 40: 377-384.

FIELD, S.G., LANGE, M., SCHULENBURG, H., VELAVAN, T.P. \& MICHIELS, N.K. 2007. Genetic diversity and parasite defense in a fragmented urban metapopulation of earthworms. Animal Conservation 10: 162-175.

FOLMER, O., BLACK, M., HOEH, W., LUTZ, R. \& VRIJENHOEK, R. 1994. DNA primers for amplification of mitochondrial cytochrome c oxidase subunit I from diverse metazoan invertebrates. Molecular Marine Biology and Biotechnology 3: 294-299.

HAJIBABAEI, M., SINGER, G.A.C., HEBERT, P.D.N. \& HICKEY, D.A. 2007. DNA barcoding: how it complements taxonomy, molecular phylogenetics and population genetics. Trends in Genetics 23: 167-172.

ISO 11268-2. 2011. Soil quality. Effects of pollutants on earthworms. Part 2. Determination of effects on reproduction to Eisenia fetida/Eisenia andrei. International Organization for Standardization, Geneva, Switzerland.

ISO 17512-1. 2005. Soil quality - Avoidance test for resting the quality of soils and effects of chemicals on behaviour. Part 1: Test with earthworms (Eisenia fetida and Eisenia andrei), International Organization for Standardization, Geneva, Switzerland

JAENICKE, J. 1982. 'Eisenia foetida' is two biological species. Megadrilogica 4: 6-8

JAMES, S.W., PORCO, D., DECAËNS, T., RICHARD, B., ROUGERIE, R. \& ERSÉUS, C. 2010. DNA barcoding reveals cryptic diversity in Lumbricus terrestris L., 1758 (Clitellata): resurrection of L. herculeus (Savigny, 1826). PLOS ONE 5: e15629.

KIMURA, M. 1980. A simple method for estimating evolutionary rate of base substitutions through comparative studies of nucleotide sequences. Journal of Molecular Evolution 16: 111-120.

KING, R.A., TIBBLE, A.L. \& SYMONDSON, W.O.C. 
2008. Opening a can of worms: unprecedented sympatric cryptic diversity within British lumbricid earthworms. Molecular Ecology 17: 4684-4698.

LOWE, C.N. \& BUTT, K.R. 2007. Earthworm culture, maintenance and species selection in chronic ecotoxicological studies: a critical review. European Journal of Soil Biology 43: S281-S288.

MABOETA, M.S., REINECKE, S.A. \& REINECKE, A.J. 2004. The relationship between lysosomal biomarker and organismal responses in an acute toxicity test with Eisenia fetida (oligochaeta) exposed to the fungicide copper oxychloride. Environmental Research 96: 95-101.

MABOETA, M.S., VAN RENSBURG, L. \& VAN RENSBURG, P.J.J. 2008. Earthworm (Eisenia fetida) bioassay to assess the possible effects of platinum tailings disposal facilities on the environment along a gradient. Applied Ecology and Environmental Research 6: 13-19.

MABOETA, M.S. \& VAN RENSBURG, L. 2003a. Bioconversion of sewage sludge and industrially produced woodchips. Water, Air and Soil Pollution 150: 219-233.

MABOETA, M.S. \& VAN RENSBURG, L. 2003b. Vermicomposting of industrially produced woodchips and sewage sludge utilizing Eisenia fetida. Ecotoxicology and Environmental Safety 56: 265-270.

MALERI, R.A., REINECKE, A.J. \& REINECKE, S.A. 2007. A comparison of nickel toxicity to pre-exposed earthworms (Eisenia fetida, Oligochaeta) in two different test substrates. Soil Biology and Biochemistry 39: 2849-2853.

MALERI, R.A., REINECKE, A.J. \& REINECKE, S.A. 2008. Metal uptake of two ecophysiologically different earthworms (Eisenia fetida and Aporrectodea caliginosa) exposed to ultramafic soils. Applied Soil Ecology 38: 42-50.

MATHIEU, J., BAROT, S., BLOUIN, M., CARO, G., DECAËNS, T., DUBS, F., DUPONT, L., JOUQUET, P. \& NAI, P. 2010. Habitat quality, conspecific density, and habitat pre-use affect the dispersal behaviour of two earthworm species, Aporrectodea icterica and Dendrobaena veneta, in a mesocosm experiment. Soil Biology and Biochemistry 42: 203-209.

MORITZ, C. \& CICERO, C. 2004. DNA Barcoding: Promise and Pitfalls. PLoS Biology 2: e354.

NOVO, M., ALMODÓVAR, A. \& DÍAZ-COSÍN, D.J. 2009. High genetic divergence of hormogastrid earthworms (Annelida, Oligochaeta) in the central Iberian Peninsula: evolutionary and demographic implications. Zoologica Scripta 38: 537-552.

NOVO, M., ALMODÓVAR, A., FERNÁNDEZ, R., TRIGO, D. \& DÍAZ-COSÍN, D.J. 2010. Cryptic speciation of hormogastrid earthworms revealed by mitochondrial and nuclear data. Molecular Phylogenetics and Evolution 56: 507-512.

OECD. 1984. Guideline for the Testing of Chemicals No. 207. Earthworm, Acute Toxicity Tests. OECDGuideline for Testing Chemicals. Paris, France

OECD. 2004. Guideline for the Testing of Chemicals No. 222. Earthworm Reproduction Test (Eisenia fetida/Eisenia andrei). Paris, France.

ØIEN, N. \& STENERSEN, J. 1984. Esterases of earthworm - III. Electrophoresis reveals that Eisenia foetida
(Savigny) is two species. Comparative Biochemistry and Physiology C 78: 277-282.

OWOJORI, O.J., REINECKE, A.J. \& ROZANOV, A.B. 2010. Influence of clay content on bioavailability of copper in the earthworm Eisenia fetida. Ecotoxicology and Environmental Safety 73: 407-414.

OWOJORI, O.J., REINECKE, A.J. \& ROZANOV, A.B. 2009. The combined stress effects of salinity and copper on the earthworm Eisenia fetida. Applied Soil Ecology 41: 277-285.

PÉREZ-LOSADA, M., BLOCH, R., BREINHOLT, J.W., PFENNINGER, M. \& DOMÍNGUEZ, J. 2012. Taxonomic assessment of Lumbricidae (Oligochaeta) earthworm genera using DNA barcodes. European Journal of Soil Biology 48: 41-47

PÉREZ-LOSADA, M., EIROA, J., MATO, S. \& DOMÍNGUEZ, J. 2005. Phylogenetic species delimitation of the earthworms Eisenia fetida (Savigny, 1826) and Eisenia andrei Bouché, 1972 (Oligochaeta, Lumbricidae) based on mitochondrial and nuclear DNA sequences. Pedobiologia 49: 317-324.

PÉREZ-LOSADA, M., RICOY, M., MARSHALL, J.C. \& DOMÍNGUEZ, J. 2009. Phylogenetic assessment of the earthworm Aporrectodea caliginosa species complex (Oligochaeta: Lumbricidae) based on mitochondrial and nuclear DNA sequences. Molecular Phylogenetics and Evolution 52: 293-302.

REINECKE, A.J., REINECKE, S.A. \& MABOETA, M.S. 2001. Cocoon production and viability as endpoints in toxicity testing of heavy metals with three earthworm species. Pedobiologia 45: 61-68.

REINECKE, A.J. \& REINECKE, S.A. 2003. The influence of exposure history to lead on the lysosomal response in Eisenia fetida (oligochaeta). Ecotoxicology and Environmental Safety 55: 30-37.

REINECKE, A.J. \& VILJOEN, S.A. 1991. A comparison of the biology of Eisenia fetida and Eisenia andrei (Oligochaeta). Biology and Fertility of Soils 1: 295-300.

REINECKE, S.A., HELLING, B. \& REINECKE, A.J. 2002. Lysosomal response of earthworm (Eisenia fetida) coelomocytes to the fungicide copper oxychloride and relation to life-cycle parameters. Environmental Toxicology and Chemistry 21: 1026-1031.

REINECKE, S.A. \& REINECKE, A.J. 2004. The comet assay as biomarker of heavy metal genotoxicity in earthworms. Archives of Environmental Contamination and Toxicology 46: 208-215.

ROUGERIE, R., DECAËNS, T., DEHARVENG, L., PORCO, D., JAMES, S.W., CHANG, C., RICHARD, B., POTAPOV, M., SUHARDJONO, Y. \& HEBERT, P.D.N. 2009. DNA barcodes for soil animal taxonomy. Pesquisa Agropecuária Brasileira 44: 789-802.

STURMBAUER, C., OPADIYA, G.B., NIEDERSTÄTTER, H., RIEDMANN, A. \& DALLINGER, R. 1999. Mitochondrial DNA reveals cryptic oligochaete species differing in cadmium resistance. Molecular Biology and Evolution 16: 967-974.

TAMURA, K., PETERSON, D., PETERSON, N., STECHER, G., NEI, M. \& KUMAR, S. 2011. MEGA5: Molecular Evolutionary Genetics Analysis using maximum likelihood, evolutionary distance, and maximum parsimony methods. Molecular Biology and Evolution 28: 2731-2739. 
VERMEULEN, L.A., REINECKE, A.J. \& REINECKE, S.A. 2001. Evaluation of the fungicide manganese-zinc ethylene bis(dithiocarbamate) (Mancozeb) for sublethal and acute toxicity to Eisenia fetida (Oligochaeta). Ecotoxicology and Environmental Safety 48: 183-189.

VOUA OTOMO, P., OWOJORI, O.J., REINECKE, S.A., DANIELS, S. \& REINECKE, A.J. 2011. Using estimates of metal bioavailability in the soil and genetic variation of allozymes to investigate heavy metal tolerance in the earthworm Eisenia fetida (Oligochaeta).
Ecotoxicology and Environmental Safety 74: 2070-2074.

VOUA OTOMO, P. \& REINECKE, S.A. 2010. Increased cytotoxic and genotoxic tolerance of Eisenia fetida (Oligochaeta) to cadmium after long-term exposure. Ecotoxicology 19: 362-368.

VOUA OTOMO, P., VAN VUUREN, B.J. \& REINECKE, S.A. 2009. Usefulness of DNA barcoding in ecotoxicological investigations: resolving taxonomic uncertainties using Eisenia Malm 1877 as an example. Bulletin of Environmental Contamination and Toxicology 82: 261-264.

Responsible Editor: B. Jansen van Vuuren 